\title{
An action research approach to facilitating the adoption of a foot health assessment tool in India
}

\author{
Michael Harrison-Blount, Michelle Cullen, Christopher J. Nester and Anita E. Williams
}

\begin{abstract}
Background: India has a diabetes population that is growing and alongside this, the incidence of limb threatening foot problems is increasing. Foot health care provision does not yet meet this demand. In one locality in India, clinicians had an unstructured approach to foot health assessments resulting in poor adoption of evidence based guidelines from the West and a persistence of serious foot complications. There was the perception that existing assessment tools did not take into account the local cultural, organizational and professional needs and there was a lack of ownership of any potential solution to the problem. Therefore, the aim of this work was to facilitate the ownership and development of a foot health assessment tool for use in the Indian context. In order to achieve this an action research approach was chosen.

Methods: Participants were facilitated through the action and implementation phases of the action research cycle by the researchers. The action phase included generating a list of potential items for inclusion in the tool from a review of the literature to provide an evidence based foundation for the foot health assessment tool. A modified Delphi method was used to further refine the contents of the tool. Members of the Delphi Panel $(n=8)$ were experts in their field of medicine and experts in delivering health care within services in India.

Results: The outcome of the study was the adoption of a locally developed foot health assessment tool (Salford Indian Foot Health Assessment Tool, SIFT). It contains thirteen sections, which reflect the risk factors identified for assessing foot health agreed by the participants to fit the Indian context. The SIFT is supported with evidence based guidelines from the West and a training program was delivered by the researchers in order to support its implementation into clinical practice.
\end{abstract}

Conclusion: An action research approach has facilitated the development and implementation of a locally created and owned foot health assessment tool. This in turn has resulted in the integration of evidence-based guidelines from the West with consideration to local cultural, organizational and professional needs and ultimately the needs of their patients. Further work is underway evaluating the outcomes of the SIFT in practice.

Keywords: Diabetes, Action research, Foot health assessment

\footnotetext{
*Correspondence: m.j.harrison-blount@salford.ac.uk

School of Health Sciences, College of Health and Social Care, University of

Salford, Frederick Road, Salford M6 6PU, UK
}

(c) 2015 Harrison-Blount et al. Open Access This article is distributed under the terms of the Creative Commons Attribution 4.0 International License (http://creativecommons.org/licenses/by/4.0/), which permits unrestricted use, distribution, and reproduction in any medium, provided you give appropriate credit to the original author(s) and the source, provide a link to the Creative Commons license, and indicate if changes were made. The Creative Commons Public Domain Dedication waiver (http://creativecommons.org/publicdomain/zero/1.0/) applies to the data made available in this article, unless otherwise stated. 


\section{Background}

India is second only to China in terms of the size of its diabetes population (65.1 million and 98 million respectively [1]), and incidence is $5.73 \%$ higher than in Europe. The complications of diabetes for the foot are preventable but can only be achieved if the complications are identified early enough and strategies provided in a timely way. With the Indian diabetes population growing it is important to support development of foot health care services by transferring evidence based guidelines from those health care contexts with established experience. However, for this to be effective and have lasting effect, the adoption of best practice must reflect health and social contexts within India and tailored to meet the needs of the local patients and organizations.

Evidence based assessment tools for the identification of foot health complications and their associated risk factors should be the cornerstone of an effective strategy for diabetes foot care in India. However, there are multiple barriers to the implementation of these assessments. It is known that there are insufficient treatment facilities, a lack of structured education programmes and there are cultural and religious influences on behaviors' related to health. These factors can often explain the late presentation of foot ulcers, walking barefoot, poor footwear, traditional healing techniques and dangerous aesthetic foot treatments [2].

Effective implementation of change in foot care services, such as the use of new assessment tools, requires a tailored approach that is sensitive to the local factors affecting change. Previous work has identified the need to use different approaches, methods and therapeutic strategies in the Eastern (or Indian) context to achieve the goal of transferring evidence based guidelines [3-5]. Furthermore research has explored the need for understanding the values required to successfully embed evidence based practice [6-8]. These values include a clear understanding of the skills and awareness of the person adopting the evidence based practice (the adopter) and the need for ensuring that the research is accessible (the innovation) and matches professional consensus (the organization) [6]. Furthermore that any education provision to support the embedding of evidence based practice must involve active participation of the adopter, with the ultimate aim of increasing knowledge and changing professional behavior [6-8]. Thus, the process through which evidence based guidelines are transferred must embrace these values.

Several authors $[6,9,10]$ advise that the characteristics of the specific context, the new knowledge, the clinicians involved and their possible interactions need to be taken into account when implementing change. An action research approach embraces these points and is carried out in collaboration "with" stakeholders within their natural context rather than them being subjects 'in' research.
In the first paper of this series [5] researchers used an action research approach to illustrate the importance of process and engagement in driving change and the adoption of evidence based practices by those associated with foot health management in India. The work utilized the problem identification and action-planning phases of the action research process [5] in order to support change in foot care in one locality in India. This was successful in achieving local ownership and identification of the clinicians own problems and, specifically, a desire to develop and implement a foot health screening/assessment tool as a potential solution.

This paper is the second part of the action research approach and uses the need for an agreed foot health assessment tool as an opportunity to facilitate local ownership of health care solutions which have evidence based practices embedded. We use the phases of action, reflection and evaluation required to complete the action research cycle. The aim of this work was to drive consensus among local health care professionals in the details of the foot assessment tool in order to create a locally agreed and owned tool for assessment of foot health status in the Indian context. Aligned with the development of the tool was the need to ensure the adoption of evidence based guidelines, whilst being aware of cultural, organizational and professional needs.

\section{Methods}

Approval for the study was obtained from the University of Salford Research, Innovation and Academic Engagement Ethical Approval Panel (Approval number HSCR12-22) and the hospital governance team at a major university hospital situated in Chennai, India.

An action research approach was adopted to ensure that the assessment tool was based on evidence based guidelines [11], whilst being culturally sensitive and applicable to local need. The foundation phase of the action research cycle has been achieved [5] and the focus of this paper is the action, reflection and evaluation phases.

Within the framework of action research processes, a consensus building approach (a modified Delphi technique) was used to facilitate definition of the foot health assessment tool. The participants were facilitated through an iterative process that used five rounds of questions, data collection and analysis techniques interspersed with feedback. It was a process through which ownership was given to the clinicians, with the results being used to define the components of a draft assessment tool that was then checked for face and construct validity. Several authors recommend a staged approach to developing an assessment tool and this was utilized during the process, [12-14]. 


\section{Stage 1 - Preliminary conceptual decisions}

To guide the development process, a list of prerequisites was created from the results of the action planning phase of the action research cycle in which the clinicians had participated and is reported in a previous paper [5]. This list of prerequisites highlights the standards that the participants feel any subsequent tool should achieve. The list can be viewed in the results section.

\section{Stage 2 - Initial category and Item generation}

A list of items were presented to participants in Round 1, relating to factors associated with diabetes foot complications, and these were generated from a focused search of the literature that used a thematic framework approach to identify content cross referenced with a review of clinical guidelines. The literature search identified 392 articles, of which 295 were excluded. Sixty one further articles were excluded because they were duplicates, did not report foot related complaints, reported on screening/assessment tools for non-foot related conditions or reported complaints or risk factors not highlighted in best practice guidelines [11]. Thirty-six studies were included in the final qualitative synthesis and were cross-referenced with national and local UK guidelines. This thematic analysis produced a list of 20 risk factors and 40 screening tests/checks for possible inclusion in the assessment tool.

\section{Stage 3 - Assessment of face and content validity}

In the context of the diabetic foot, validity refers to the degree to which the assessment measures the risk factors presenting in the lower limb. Face validity is the lowest level of validity and based upon the personal opinions of the observer. Content validity is determined by theoretical reasoning that a foot health assessment tool adequately measures selected foot health variables. When a foot health assessment tool is believed to include the domains that are required to adequately assess the foot its content is considered valid (content validity). We achieved consensus on the items to be included in the tool as well as the phrasing of such items and this process also enhanced the ownership of the assessment tool.

\section{Stage 4 - Field trials to assess consistency and construct validity}

The assessment tool created by the clinicians (Salford Indian Foot Health Assessment Tool (SIFT)) was piloted to begin the process of assessing consistency, to achieve construct validity and to allow clinicians to test local implementation of their own solution. This process will continue following completion of the Delphi and will be reported in a follow up paper.

An overview of the Delphi process can be seen in Fig. 1.

\section{Selection of Delphi panel members}

The authors recruited to the Delphi panel those participants who had taken part in the first phase of the action research model [5], as it would be these clinicians who would be embedding the evidence base into clinical practice. This provided continuity through the subsequent action and implementation phases. Although not experts in the assessment and triage of foot health, this was not necessary, since they were all experts within their chosen disciplines and in the Indian health care context. This knowledge was the foundation of their role in the Delphi process, since what is 'evidence based' in clinical terms was established through the literature and existing guidelines search in the initial category and item generation phases.

The term item is used to mean both the risk factors and tests/assessments used. Previous authors have stated that consensus is reached when a positive response level of $75 \%$ or greater from the participants is reached [12-17].

\section{Round 1}

Information about the aim of their participation, the methods used and invitation to be part of the change process was sent to the participants. The researchers sent the initial list of possible risk factors for inclusion in the foot health assessment tool to the participants. This was the list derived from the initial literature search and the information participants had already reported as list of criteria they would deem important in a foot assessment tool from a previous focus group [5]. This provided early ownership of the knowledge to be discussed, free from the influence of peers and the dynamics of group discussions. The aim was to collect information on each participant's opinion regarding the importance of each risk factor. To help the decision making process the authors also included a summary of the evidence that supported each risk factor. Participants were asked to rate the importance of inclusion of each risk factor using a Likert scale (5 being essential to include and 1 being essential to remove). The authors also gave participants the opportunity to comment on any of the risk factors included in the tool. Responses were accumulated to devise an agreed criteria list, which was then sent out for comments and amendments in round 2.

\section{Round 2}

The researchers used the results of round 1 to select risk factors for which there were high levels of agreement for inclusion/exclusion from the final tool. Risk factors that rated as 5 and 4 by at least $75 \%$ (6 participants) were included. Risk factors rated, as 3 by at least $75 \%$ of the members were included in this round to allow for re consideration and those rated as 2 and 1 were excluded.

For round 2 the participants were asked to review the comments or amendments made to the risk factors in 


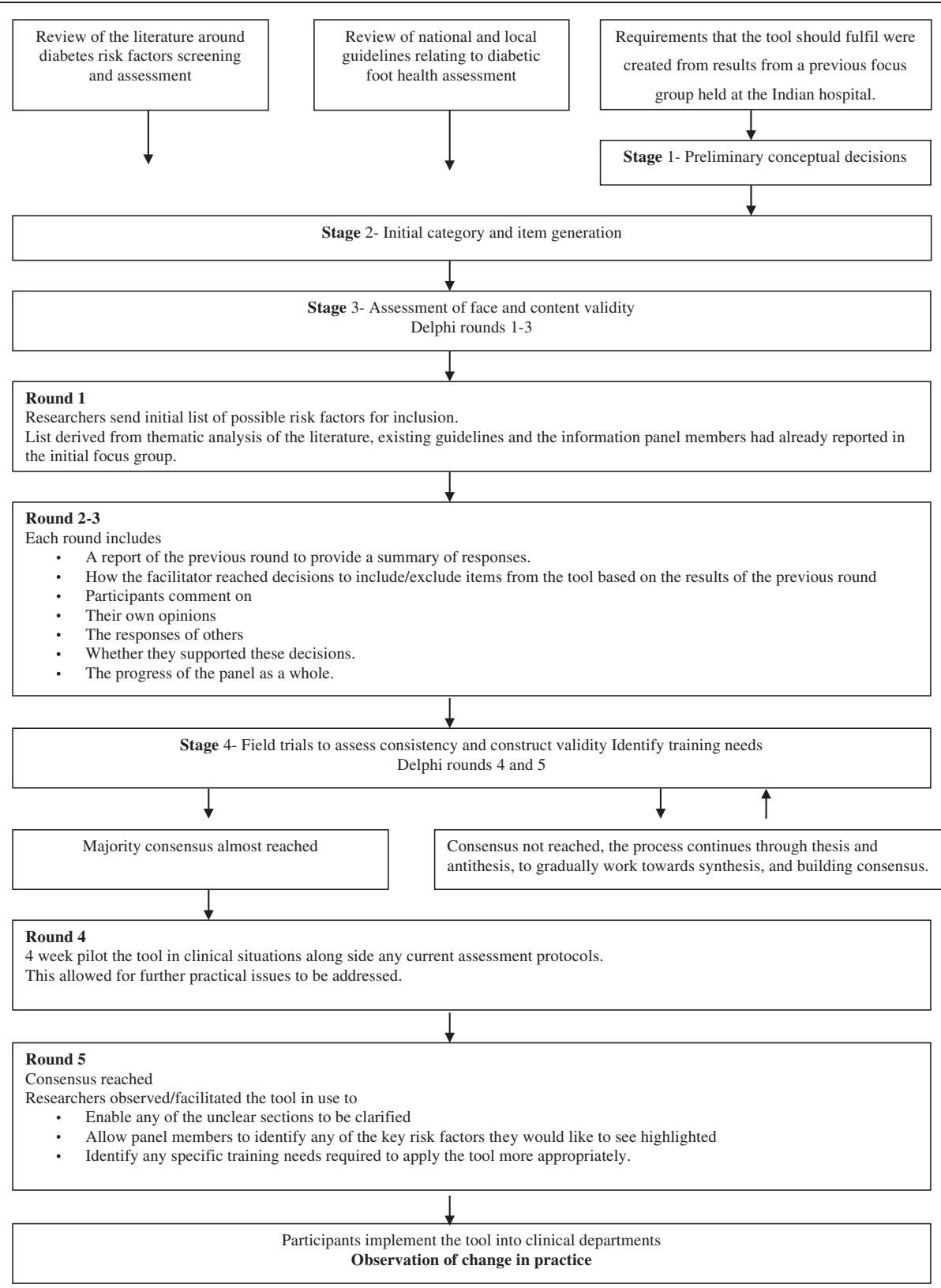

Fig. 1 The Delphi procedure-overview of the process

round 1 and re-evaluate any of those risks. At this stage panel members were provided with the tests/assessments to be used to evaluate each risk factor and again asked to rate their inclusions on a Likert scale ( 5 being essential to include and 1 to be removed). Again panel members were given the opportunity to provide comments and additionally participants were asked: Would you like to see a number of key Risk factors highlighted on the final assessment tool? And do you endorse the Delphi procedure so far? If no please give details of the aspects of the procedure which you do not support and list any suggestions you have for improvement. This latter question challenged participants to acknowledge their participation in a group exercise and reaffirm their belief in its progress. This was important to bolster confidence in the process in which they were engaged and to validate their contributions as 'valued'.

\section{Round 3}

The results of round 2 were used to select the final risk factors, tests and assessments for inclusion in the final tool. Risk factors rated 3 at round 2 that had been re-rated as 5 and 4 by at least $75 \%$ of the participants who replied in this 
round were selected for inclusion in the final tool. Items that remained rated as 3 or had been re-rated as 2 or 1 were excluded.

Tests/assessments that rated as 5 and 4 by at least $75 \%$ of the participants who replied in this round were selected for inclusion in the tool. Tests/assessments rated, as 3 by at least $75 \%$ of the members were included for the next round to allow for re consideration and those rated as 2 and 1 were excluded.

This third round asked the panelists to review the inclusion and exclusion results for both items and to indicate whether they thought that an item should be included or excluded. Participants were also asked to comment on any item that they would like to rephrase or whether they wished to add an item to the tool and to provide suggestions of such changes.

\section{Round 4 (Pilot)}

The results of round 3 were used to select any rephrased or additional items to be included in the foot health assessment tool. Risk factors and tests/assessments selected for inclusion at this stage were presented to the participants for them to indicate whether they agreed with the proposed rephrasing or additional items, and if not to suggest alternatives. Risk factors and tests/assessments that rated as 5 and 4 by at least $75 \%$ of the participants who replied in this round were selected for inclusion in the tool. Risk factors and tests/assessments rated as 3 by at least $75 \%$ of the members were included for the next round to allow for re consideration and those rated as 2 and 1 were excluded.

This provided a new level of contribution by participants, such as rewording specific items, and thus provided ownership of the precise details and language used.

The clinicians who had been part of the process were asked to pilot the tool over a 4-week period on patients presenting with foot health problems within their own specific disciplines. This brought to life their own efforts in practical terms, in front of their colleagues and patients, and thus reinforced the productivity of the exercise in which they had participated. They were asked to consider, the practicalities of the risk factors and tests/ assessments for suggested inclusion in the final tool, how the test and assessments would be recorded, any further additions they may want to make to the tool and to suggest solutions and alternatives to any comments made. Participants were asked to record their decision using either yes, no or unclear with consensus reached at a level of $75 \%$ agreement as with previous rounds. Additionally participants were asked to record any further items they would like to have considered for inclusion in the tool following the pilot. These were recorded as a list and distributed to the participants.

\section{Round 5 (Visit) modification of the Delphi procedure}

This modification allowed the researchers to see the tool being used in a clinical setting in order to influence the development stages thereby improving face validity and overcoming the potential interpretation difficulties. The results of round 4 were used to select the content of the final foot health assessment tool. All current and additional items rated as 'yes' by at least $75 \%$ of the participants who replied in this round were selected for inclusion in the final tool. All current and additional items rated as 'no' by at least $75 \%$ of the participants who replied in this round were excluded. We considered responses regarding items marked as 'unclear' by at least $75 \%$ and asked the respondents to revisit the guidelines for clarification.

In round 5 the final version of the Salford Indian Foot Health Assessment Tool (SIFT) and the guidelines were presented to the panel members for use. The researchers spent one week with participants in order to provide support and to identify any specific training needs.

Table 1 Participants involvement and clinical specialties

\begin{tabular}{lll}
\hline Participant (P) code & Role & Agreement to take part in the process \\
\hline P1 & Consultant General Physician (Head of service) & Agreed \\
P2 & Consultant General Physician & Requested not to take part \\
P3 & Consultant Dermatologist & Agreed \\
P4 & Orthopaedic surgeon (Lead member of staff, key contact) & Agreed \\
P5 & General surgeon (Head of service) & Agreed \\
P6 & Consultant Sports Medicine & Agreed \\
P7 & Consultant Diabetologist (Lead member of staff, key contact) & Agreed \\
P8 & Head of Physiotherapy & Agreed \\
P9 & Head orthotist & Agreed \\
P10 & Consultant Vascular Surgeon (Head of service) & Requested not to take part \\
P11 & Consultant endocrinologist (Head of service) & Requested not to take part \\
\hline
\end{tabular}




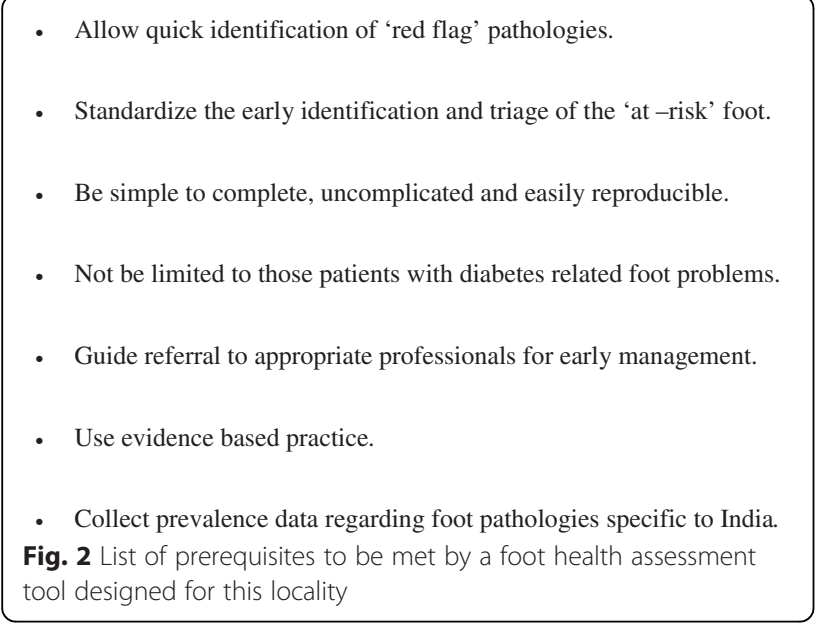

\section{Results}

Eight of the eleven clinicians invited to take part consented to participate in the Delphi procedure. The specialties of the clinicians are listed in Table 1.

\section{Preliminary conceptual decisions}

The researchers and participants of the focus group in the problem identification and action planning stages decided that the foot health assessment tool should have the following prerequisites (Fig. 2).

\section{Delphi rounds 1-3: Assessment of face and content validity}

The result of this study was the design of a foot health assessment tool (SIFT) developed by those who would use it in clinical practice. This was achieved using a modified Delphi method embedded in an action research process, which aims to facilitate change through ownership.

\section{Delphi Round 1}

All eight of the participants who agreed to take part in the procedure returned completed questionnaires. Following the results of this round, ten risk factors were selected for inclusion, eight risk factors were removed from the tool as they were rerated at 1 or 2 on the likert scale by $>75 \%$ of the participants and 2 risk factors were put forward to be rerated as part of round 2 (Table 2).

\section{Delphi round 2}

Of the eight practitioners involved with the process seven returned completed questionnaires. The eighth member of the panel had reported being too busy this time to take part, but still wished to be part of further rounds.
Table 2 Delphi results: Round 1

\begin{tabular}{llll}
\hline $\begin{array}{l}\text { Original 20 risk factors identified } \\
\text { for possible inclusion }\end{array}$ & $\begin{array}{l}\text { \% expert } \\
\text { acceptance }\end{array}$ & $\begin{array}{l}\text { Likert } \\
\text { rating }\end{array}$ & $\begin{array}{l}\text { Feedback put } \\
\text { forward for } \\
\text { round 2 }\end{array}$ \\
\hline Infection & 100 & $4-5$ & To be included \\
Ischemia & 100 & & \\
Neuropathy & 88 & & \\
Ulceration current & 88 & & \\
Deformity & 88 & & \\
Dermatological & 75 & & \\
Amputation & 88 & & \\
Smoking & 100 & & \\
Footwear & 88 & & \\
Charcot & 88 & & \\
Vascular surgery & 88 & 3 & To be rerated \\
Ulceration previous & 88 & & \\
Trauma & 75 & $1-2$ & To be excluded \\
Education & 88 & & \\
Age socioeconomic & 100 & & \\
Plantar pressures & 88 & & \\
Self care & 88 & & \\
Retinopathy/visual impairment & 100 & & \\
Nephropathy & 88 & & \\
Glycaemia & 88 & & \\
\hline
\end{tabular}

Following the results of this round, the ten risk factors selected for inclusion were not challenged and would therefore be included in the final tool. The eight risk factors removed from the tool were all agreed and therefore excluded from the process. The two risk factors where consensus had not been reached had been rerated, one to be included in the final tool and the other to be amended, and then added to the final tool (Table 3).

The results following this round found that 5 risk factors would be assessed by a yes or no option, fifteen further tests/methods of assessment were selected for inclusion, fourteen tests/assessment methods were removed from the tool, including two that had not been sent to participants as the risk factor they assessed had already been excluded in a previous round. Ten tests/assessment methods were put forward to be rerated in round 3 (Table 3 ).

In this round six of the seven participants were in favor of seeing a number of key risk factors highlighted on the final assessment tool. The member of the panel who stated they were 'unclear' about highlighting certain risk factors went on to explain that they felt this could only be done if 'it did not over complicate the tool and make it difficult for all staff to use and make sense of' as the majority of members were in favor of this, the researchers decided to investigate highlighting the risk 
Table 3 Delphi results: Round 2 Consensus for risk factors and tests/assessments

\begin{tabular}{|c|c|c|c|c|c|c|c|}
\hline \multicolumn{4}{|c|}{ Round 2 consensus for risk factors } & \multicolumn{4}{|c|}{ Round 2 consensus for tests/assessments } \\
\hline $\begin{array}{l}\text { Risk factors confirmed for } \\
\text { inclusion in the final tool }\end{array}$ & $\begin{array}{l}\text { \% expert } \\
\text { acceptance }\end{array}$ & $\begin{array}{l}\text { Likert } \\
\text { rating }\end{array}$ & $\begin{array}{l}\text { Comments or } \\
\text { amendments on } \\
\text { previous round }\end{array}$ & $\begin{array}{l}\text { Original list of Tests/assessments } \\
\text { for possible inclusion }\end{array}$ & $\begin{array}{l}\text { \% expert } \\
\text { acceptance }\end{array}$ & $\begin{array}{l}\text { Likert } \\
\text { rating }\end{array}$ & $\begin{array}{l}\text { Feedback put } \\
\text { forward for } \\
\text { round } 3\end{array}$ \\
\hline Infection & 100 & $4-5$ & Not challenged & $\begin{array}{l}\text { Visual assessment of Redness, } \\
\text { warmth, Pus, odor, swelling }\end{array}$ & 100 & $4-5$ & To be included \\
\hline \multirow[t]{8}{*}{ Ischemia } & 100 & & & DP/TP pulses & 100 & $4-5$ & To be included \\
\hline & & & & Temp touch & 86 & & \\
\hline & & & & ABPI & 86 & $1-2$ & To be excluded \\
\hline & & & & Doppler & 86 & & \\
\hline & & & & CRT & 86 & & \\
\hline & & & & $\mathrm{TBI}$ & 100 & & \\
\hline & & & & Duplex & 100 & & \\
\hline & & & & TcPO2 & 100 & & \\
\hline \multirow[t]{7}{*}{ Neuropathy } & 100 & & & Monofilament & 100 & $4-5$ & To be included \\
\hline & & & & Tuning fork & 100 & & \\
\hline & & & & Vibratip & 100 & $1-2$ & To be excluded \\
\hline & & & & Ipswitch touch test & 100 & & \\
\hline & & & & Ankle reflex & 100 & & \\
\hline & & & & Neurotip & 86 & & \\
\hline & & & & Biothesiometer & 100 & & \\
\hline Ulceration current & 100 & & & Yes/no & 100 & $4-5$ & To be included \\
\hline \multirow[t]{5}{*}{ Deformity } & 100 & & & Charcot & 100 & $4-5$ & To be included \\
\hline & & & & Claw/hammer toes & 100 & 3 & To be rerated \\
\hline & & & & HAV & 86 & & \\
\hline & & & & Flat foot & 100 & & \\
\hline & & & & Prom Met heads & 100 & & \\
\hline \multirow[t]{9}{*}{ Dermatological } & 100 & & & Corns and Callus & 86 & $4-5$ & To be included \\
\hline & & & & Dry & 86 & & \\
\hline & & & & Cracked & 100 & & \\
\hline & & & & Fungal & 86 & & \\
\hline & & & & Blisters & 100 & & \\
\hline & & & & Extravasation tissue & 86 & & \\
\hline & & & & Maceration & 86 & & \\
\hline & & & & Nail problems & 86 & 3 & To be rerated \\
\hline & & & & Atrophy & 86 & $1-2$ & To be excluded \\
\hline Amputation & 100 & & & Yes/no & 100 & $4-5$ & To be included \\
\hline Smoking & 100 & & & Yes/no & 100 & $4-5$ & To be included \\
\hline \multirow[t]{5}{*}{ Footwear } & 100 & & & Style & 100 & $4-5$ & To be included \\
\hline & & & & Toe box & 100 & 3 & To be rerated \\
\hline & & & & Wear & 100 & & \\
\hline & & & & Insoles & 100 & & \\
\hline & & & & Fit & 100 & & \\
\hline
\end{tabular}


Table 3 Delphi results: Round 2 Consensus for risk factors and tests/assessments (Continued)

\begin{tabular}{|c|c|c|c|c|c|c|c|}
\hline & & & & Condition & 86 & & \\
\hline Charcot & 100 & & & $\begin{array}{l}\text { Visual assessment of redness, } \\
\text { unilateral temp difference, } \\
\text { swelling }\end{array}$ & 100 & $4-5$ & To be included \\
\hline Vascular surgery & 86 & $4-5$ & $\begin{array}{l}\text { Vascular surgery altered to } \\
\text { Significant surgical history }\end{array}$ & Yes/no & 100 & $4-5$ & To be included \\
\hline Ulceration previous & 86 & & Included & Yes/no & 100 & $4-5$ & To be included \\
\hline Trauma & 86 & $1-2$ & Not challenged & & & & \\
\hline Education & 86 & & & & & & \\
\hline Age socioeconomic & 100 & & & & & & \\
\hline Plantar pressures & 86 & & & & & & \\
\hline Self care & 86 & & & & & & \\
\hline $\begin{array}{l}\text { Retinopathy/visual } \\
\text { impairment }\end{array}$ & 100 & & & & & & \\
\hline Nephropathy & 86 & & & & & & \\
\hline Glycaemia & 86 & & & & & & \\
\hline
\end{tabular}

factors in round five during observation of its use in practice. At this stage all seven of the panel members reported that they endorsed the Delphi procedure so far and were happy to continue with the process.

\section{Delphi round 3}

All eight of the practitioners involved with the process returned completed questionnaires.

Following the results of this round the twenty tests/assessment methods selected for inclusion were not challenged and would therefore is included in the final tool. The twelve tests/assessment methods removed from the tool were all agreed and therefore excluded from the process. Of the ten tests/assessment methods where consensus had not been reached and had been rerated, one was included into the final assessment tool and the remaining nine were excluded from the process (Table 4).

The additional results in this round report those items that the panel wished to rephrase or add. During this round no additional risk factors were added, four risk factors were rephrased, one was subdivided into two, and four were categorized under one of the other existing risk factors and therefore were moved into the tests/ assessment methods section. In addition twelve further test/methods of assessment were added, two of which had further subdivisions, four were rephrased and three were subdivided (Table 5).

Panel members were also asked in this round if they agreed with the procedure of being asked whether they would support the instructions issued in round 4 and whether they would be willing to comment on any changes. All eight panel members agreed to this process.
Delphi rounds 4 \& 5: Field trials to assess consistency and construct validity

Field trials to assess consistency and construct validity are ongoing, as at this stage we have not undertaken any formal quantitative analysis. The first stages of the validation process have begun by piloting the tool in clinical practice.

\section{Delphi round 4}

All eight of the practitioners involved with the process returned completed questionnaires and took part in the pilot of the tool over a four week period, on patients presenting with foot health problems within their own specific disciplines, where they were asked to consider the practicalities of the tool in a clinical setting.

Following the results of the completed questionnaires the eight risk factors chosen and where rephrased were not challenged and therefore included in the pilot tool. Of the thirty one tests/assessment methods chosen, none of the rephrased or additional items were challenged and therefore included in the pilot tool. No alternatives were suggested for any of the current items (Table 6).

All of the proposed risk factors were marked 'yes' by the panelists in response to the question of practicality. Panelists marked 3 methods of recording risk factors as 'No' and 1 was marked as unclear. It was felt by the panelists that previous amputation should be recorded as a yes/no followed by the site and whether it was traumatic, surgical or auto amputation. It was further felt that the recording of skin and nail conditions should also be done by circling yes or no, and that location of lesions should be recorded on pictures of both a left and right foot. Other lesions to be recorded here include amputations and current ulcers. Smoking was marked as unclear by $6(75 \%)$ of the panelists as they felt that this was not specific enough due to the 
Table 4 Delphi results: Round 3

\begin{tabular}{|c|c|c|c|}
\hline $\begin{array}{l}\text { Original } 20 \text { tests/ } \\
\text { assessments identified } \\
\text { for possible inclusion }\end{array}$ & $\begin{array}{l}\% \text { expert } \\
\text { acceptance }\end{array}$ & $\begin{array}{l}\text { Likert } \\
\text { rating }\end{array}$ & $\begin{array}{l}\text { Comments or } \\
\text { amendments on } \\
\text { previous round }\end{array}$ \\
\hline $\begin{array}{l}\text { Infection - Visual } \\
\text { assessment }\end{array}$ & 100 & \multirow[t]{20}{*}{$4-5$} & \multirow[t]{20}{*}{$\begin{array}{l}\text { Not challenged and } \\
\text { therefore included }\end{array}$} \\
\hline DP/TP pulses & 100 & & \\
\hline Temp touch & 100 & & \\
\hline Monofilament & 100 & & \\
\hline Tuning fork & 100 & & \\
\hline $\begin{array}{l}\text { Ulceration } \\
\text { current - yes/no }\end{array}$ & 100 & & \\
\hline $\begin{array}{l}\text { Ulceration previous - } \\
\text { yes no }\end{array}$ & 100 & & \\
\hline Deformity - Charcot & 100 & & \\
\hline Corns and Callus & 100 & & \\
\hline Dry & 100 & & \\
\hline Cracked & 100 & & \\
\hline Fungal & 100 & & \\
\hline Blisters & 100 & & \\
\hline Extravasation tissue & 100 & & \\
\hline Maceration & 100 & & \\
\hline Amputation - yes/no & 100 & & \\
\hline Smoking - yes/no & 100 & & \\
\hline Footwear - style & 100 & & \\
\hline $\begin{array}{l}\text { Charcot - Visual } \\
\text { assessment }\end{array}$ & 100 & & \\
\hline $\begin{array}{l}\text { Significant Surgical } \\
\text { History- yes/no }\end{array}$ & 100 & & \\
\hline Nail problems & 88 & $4-5$ & Included \\
\hline ABPI & 88 & \multirow[t]{12}{*}{$1-2$} & \multirow{12}{*}{$\begin{array}{l}\text { Not challenged and } \\
\text { therefore excluded } \\
\text { from the process }\end{array}$} \\
\hline Doppler & 75 & & \\
\hline CRT & 88 & & \\
\hline $\mathrm{TB} \mid$ & 100 & & \\
\hline Duplex & 100 & & \\
\hline TcPO2 & 100 & & \\
\hline Vibratip & 100 & & \\
\hline Ipswitch touch test & 100 & & \\
\hline Ankle reflex & 100 & & \\
\hline Neurotip & 88 & & \\
\hline Biothesiometer & 100 & & \\
\hline Atrophy & 100 & & \\
\hline
\end{tabular}

differing methods of tobacco use in India which include smoking, chewing and snuff (Table 7).

The panelists also suggested that a number of sections be added to the final assessment tool which had not been considered until the tool had been used in practice (Table 8).
At this stage all eight of the panel members reported that they endorsed the Delphi procedure following a review of the aims and purpose. Additionally all eight panel members reported use of the evidence provided and the feedback from the previous rounds. Two members stated that although they had read the evidence initially they used the feedback predominantly to inform and support their decisions as the evidence document took time to read in what were already busy clinics for them to manage.

\section{Delphi round 5}

All eight of the practitioners involved with the process agreed to being observed using the tool within their own departments.

At this stage the panel members used the tool and the researchers observed it in use for one week within the hospital. All panel members agreed on the alterations to the way in which amputations, skin and nail conditions were recorded via a yes/no structure and the recording of the sites of the skin and nail conditions onto pictures. No panel members recorded any items as 'unclear' (Table 9). Six of the items proposed for additional inclusion were accepted by all of the panel members and therefore added to the final tool. The item Diagnosis/ summary however was felt by seven members of the panel (88\%) to be unnecessary. It was argued that as the tool collects multiple pieces of data it would also produce many possible diagnoses, which would be, prioritized differently depending on the specialist using the tool. It was further expressed that this was not required as the additional classification category provided enough information about risk, to guide the management steps appropriately. The diagnosis/summary section was therefore excluded from the final tool (Table 10).

The tool is structured as a list of thirteen sections made up of the risk factors identified during this investigation. Each of those sections contains subsections made up of the relevant tests, assessment methods and visual checks used to identify foot pathologies. The participants agreed that the following items (Table 11) were to be highlighted as 'red flags' and should therefore alert a rapid referral to the appropriate department. Participants requested that these items were highlighted on the tool with a capital letter $\mathrm{R}$. The final tool is presented in Additional file 1. The clinical content of tool itself is not greatly dissimilar to foot health assessment tools developed in the West, this however is not surprising as the guidelines on which SIFT was based were mostly developed in the West. More importantly the opportunity for the clinicians to be participatory in the process has developed a tool where the structure and format are born out of the Indian health care system and subsequent adoption has taken place as a result of the participation in its development. A more detailed description of each 
Table 5 Delphi results: Round 3

\begin{tabular}{|c|c|c|c|c|}
\hline $\begin{array}{l}\text { Risk factors put forward for } \\
\text { rephrasing or subdivision }\end{array}$ & $\begin{array}{l}\text { Suggested } \\
\text { rephrasing or } \\
\text { subdivision }\end{array}$ & $\begin{array}{l}\text { Tests/assessments put forward for } \\
\text { rephrasing recategorizing or } \\
\text { subdivision }\end{array}$ & $\begin{array}{l}\text { Suggested rephrasing, } \\
\text { recategorizing or } \\
\text { subdivision }\end{array}$ & $\begin{array}{l}\text { Suggested tests/assessments } \\
\text { to be added to current list }\end{array}$ \\
\hline Infection & Cellulitis & $\begin{array}{l}\text { Visual assessment of Redness, } \\
\text { warmth, Pus, odor, swelling }\end{array}$ & $\begin{array}{l}\text { Yes/no Move to skin } \\
\text { conditions }\end{array}$ & \\
\hline \multirow[t]{4}{*}{ Deformity } & & & & Amputation \\
\hline & & & & Forefoot \\
\hline & & & & Rear foot \\
\hline & & & & Other \\
\hline \multirow[t]{4}{*}{ Ischemia } & \multirow{4}{*}{$\begin{array}{l}\text { Peripheral vascular } \\
\text { assessment }\end{array}$} & \multirow[t]{3}{*}{ DP/TP pulses } & \multirow[t]{3}{*}{ Palpable - Yes/no } & Intermittent claudication \\
\hline & & & & Oedema \\
\hline & & & & Rest pain \\
\hline & & Temp touch & Normal /Abnormal & \\
\hline \multirow[t]{2}{*}{ Neuropathy } & \multirow{4}{*}{$\begin{array}{l}\text { Neurological } \\
\text { assessment }\end{array}$} & Monofilament & 10 sites for monofilament & \\
\hline & & Tuning fork & $\begin{array}{l}\text { Hypo pigmented skin } \\
\text { lesions }\end{array}$ & \\
\hline Ulceration current & & Yes/no & Move to skin conditions & \\
\hline Ulceration previous & & Yes/no & & \\
\hline \multirow[t]{8}{*}{ Dermatological } & \multirow[t]{3}{*}{ Skin conditions } & Maceration & Hyperhydrotic & Normal \\
\hline & & Dry & Hypohydrotic & Interdigital rash \\
\hline & & Cracked & Fissure & Cellulitis \\
\hline & \multirow[t]{5}{*}{ Nail conditions } & & & onychauxis \\
\hline & & & & onychomycosis \\
\hline & & & & paronychia \\
\hline & & & & onychocryptosis \\
\hline & & & & other \\
\hline Amputation & & Yes/no & Move to deformity & \\
\hline \multirow[t]{5}{*}{ Footwear } & & Style & Type & Habits \\
\hline & & & & Worn always \\
\hline & & & & Outdoors only \\
\hline & & & & never \\
\hline & & & & Indoors only \\
\hline Charcot & & $\begin{array}{l}\text { Visual assessment of Redness, } \\
\text { unilateral temp difference, swelling }\end{array}$ & Yes/no Move to deformity & \\
\hline
\end{tabular}

section together with the corresponding evidence base were issued to the participants to support implementation and to act as a reference once the researchers had withdrawn from the location on completion. The guidelines and use of the tool in round 5 identified possible training needs for the participants and potentially for others who may also wish to use the tool at this site. Therefore in conjunction with the guidelines the researchers also developed and delivered a short foot health assessment and management training program entitled 'Principles of lower limb assessment and management' (Additional file 2). The SIFT was subsequently adopted by the hospital and used in practice. To date the tool has been used 2,622 times.

\section{Discussion}

Through the action research approach researchers facilitated the process whereby clinicians took local ownership of a clinical problem, developed their own solution i.e. the Salford Indian Foot health assessment Tool (SIFT) and embedded it into their practice. Through this approach researchers identified the knowledge and skills of the adopters, made the research evidence accessible and using Delphi ensured the adopters actively participated in reaching professional consensus on how that research evidence was embraced and embedded into practice [18]. This is the first time an action research approach has been used to drive change in Indian foot health care services 
Table 6 Delphi results - Round four consensus on rephrased items and additional tests/assessments

\begin{tabular}{|c|c|c|c|c|c|c|c|}
\hline \multicolumn{6}{|c|}{ Round four consensus on rephrased items } & \multicolumn{2}{|c|}{$\begin{array}{l}\text { Round four consensus on } \\
\text { additional assessments/tests }\end{array}$} \\
\hline $\begin{array}{l}\text { Risk factors for } \\
\text { inclusion }\end{array}$ & $\begin{array}{l}\text { Suggested risk factors } \\
\text { to be rephrased or } \\
\text { subdivided }\end{array}$ & $\begin{array}{l}\% \text { expert } \\
\text { consensus }\end{array}$ & $\begin{array}{l}\text { Tests/assessments for } \\
\text { inclusion }\end{array}$ & $\begin{array}{l}\text { Suggested tests/ } \\
\text { assessments to be } \\
\text { rephrased or subdivided }\end{array}$ & $\begin{array}{l}\% \text { expert } \\
\text { consensus }\end{array}$ & $\begin{array}{l}\text { Suggested tests } \\
\text { assessments to } \\
\text { be added }\end{array}$ & $\begin{array}{l}\% \text { expert } \\
\text { consensus }\end{array}$ \\
\hline Infection & Cellulitis & 100 & $\begin{array}{l}\text { Visual assessment of } \\
\text { Redness, warmth, Pus, } \\
\text { odor, swelling }\end{array}$ & $\begin{array}{l}\text { Yes/no Move to skin } \\
\text { conditions }\end{array}$ & 100 & & \\
\hline \multirow[t]{3}{*}{ Ischemia } & $\begin{array}{l}\text { Peripheral vascular } \\
\text { assessment }\end{array}$ & 100 & DP/TP pulses & Palpable - Yes/no & 100 & $\begin{array}{l}\text { Intermittent } \\
\text { claudication }\end{array}$ & 100 \\
\hline & & & Temp touch & Normal/Abnormal & 100 & Oedema & 100 \\
\hline & & & & & & Rest pain & 86 \\
\hline \multirow[t]{4}{*}{ Deformity } & & & & & & Amputation & 100 \\
\hline & & & & & & Forefoot & 75 \\
\hline & & & & & & Rear foot & 75 \\
\hline & & & & & & Other & 75 \\
\hline \multirow[t]{2}{*}{ Neuropathy } & $\begin{array}{l}\text { Neurological } \\
\text { assessment }\end{array}$ & 100 & Monofilament & $\begin{array}{l}10 \text { sites for } \\
\text { monofilament }\end{array}$ & 86 & & \\
\hline & & & Tuning fork & $\begin{array}{l}\text { Hypo pigmented skin } \\
\text { lesions }\end{array}$ & 100 & & \\
\hline $\begin{array}{l}\text { Ulceration } \\
\text { current }\end{array}$ & & & Yes/no & Move to skin conditions & 86 & & \\
\hline $\begin{array}{l}\text { Ulceration } \\
\text { previous }\end{array}$ & & & Yes/no & & & & \\
\hline \multirow[t]{8}{*}{ Dermatological } & Skin conditions & 86 & Maceration & Hyperhydrotic & 100 & Normal & 100 \\
\hline & & & Dry & Hypohydrotic & 100 & Interdigital rash & 75 \\
\hline & & & Cracked & Fissure & 75 & Cellulitis & 86 \\
\hline & Nail conditions & & & & & onychauxis & 75 \\
\hline & & & & & & onychomycosis & 75 \\
\hline & & & & & & paronychia & 75 \\
\hline & & & & & & onychocryptosis & 75 \\
\hline & & & & & & other & 75 \\
\hline Amputation & & & Yes/no & Move to deformity & 100 & & \\
\hline \multirow[t]{5}{*}{ Footwear } & & & Style & Type & 100 & Habits & 86 \\
\hline & & & & & & Worn always & 100 \\
\hline & & & & & & Outdoors only & 100 \\
\hline & & & & & & never & 100 \\
\hline & & & & & & Indoors only & 100 \\
\hline Charcot & & & $\begin{array}{l}\text { Visual assessment of } \\
\text { redness, unilateral temp } \\
\text { difference, swelling }\end{array}$ & $\begin{array}{l}\text { Yes/no Move to } \\
\text { deformity }\end{array}$ & 100 & & \\
\hline
\end{tabular}

The Delphi process has been a useful method for both data collection and to achieve consensus with the participants [19, 20]. Delphi was employed as a tool embedded within the ethos of action research. Active participation of the adopters in this process has proven to be effective as a vehicle to embed evidence into practice, facilitate ownership of the solutions thereby sustaining change within their clinical practice [21].
It is generally considered that the Delphi technique requires 'experts' to be the participants, however, it can still be used where no experts exist [23]. In the west, podiatrists are considered the experts in the care of foot problems $[3,11]$ but in India there are no locally trained podiatrists within its healthcare system. However, although the participants were not experts in the area of foot health assessment they were experts in how foot 
Table 7 Delphi results: Round 4-Pilot of the tool

\begin{tabular}{|c|c|c|c|c|c|c|}
\hline $\begin{array}{l}\text { Risk factors confirmed } \\
\text { for inclusion in the } \\
\text { Pilot tool }\end{array}$ & $\begin{array}{l}\text { Practicality of } \\
\text { proposed risk } \\
\text { factor }\end{array}$ & $\begin{array}{l}\% \text { expert } \\
\text { consensus }\end{array}$ & $\begin{array}{l}\text { Tests and assessment } \\
\text { methods confirmed for } \\
\text { inclusion in the Pilot tool }\end{array}$ & $\begin{array}{l}\text { Method of recording } \\
\text { tests and assessment } \\
\text { methods }\end{array}$ & $\begin{array}{l}\text { Practicality of proposed } \\
\text { test/assessment and } \\
\text { method of recording }\end{array}$ & $\begin{array}{l}\% \text { expert } \\
\text { consensus }\end{array}$ \\
\hline \multirow{5}{*}{$\begin{array}{l}\text { Peripheral vascular } \\
\text { assessment }\end{array}$} & \multirow[t]{5}{*}{ Yes } & \multirow[t]{5}{*}{100} & DP/TP pulses palpable & Yes/no & Yes & 100 \\
\hline & & & Temp touch & Normal/Abnormal & Yes & 100 \\
\hline & & & Intermittent claudication & Yes/no & Yes & 100 \\
\hline & & & Oedema Present & Yes/no & Yes & 100 \\
\hline & & & Rest pain & Yes/no & Yes & 100 \\
\hline \multirow[t]{2}{*}{$\begin{array}{l}\text { Neurological } \\
\text { assessment }\end{array}$} & \multirow[t]{2}{*}{ Yes } & \multirow[t]{2}{*}{100} & Monofilament & $\begin{array}{l}10 \text { sites } \\
\text { Hypopigmented skin } \\
\text { lesions }\end{array}$ & Yes & 86 \\
\hline & & & Vibration & $\begin{array}{l}\text { Left/Right Normal/ } \\
\text { Absent/reduced }\end{array}$ & Yes & 100 \\
\hline \multirow[t]{4}{*}{ Deformity } & \multirow[t]{4}{*}{ Yes } & \multirow[t]{4}{*}{100} & Charcot & Yes/no & Yes & 100 \\
\hline & & & Amputation & $\begin{array}{l}\text { Site and Surgical/ } \\
\text { traumatic/auto }\end{array}$ & No & 75 \\
\hline & & & Forefoot & $\begin{array}{l}\text { Specific toe/site Left } \\
\text { and right }\end{array}$ & Yes & 100 \\
\hline & & & Rear foot & $\begin{array}{l}\text { Foot posture RCSP } \\
\text { Normal/pronated/ } \\
\text { supinated }\end{array}$ & Yes & 75 \\
\hline \multirow[t]{13}{*}{ Skin conditions } & \multirow[t]{13}{*}{ Yes } & \multirow[t]{13}{*}{100} & Fungal & Tick box & \multirow[t]{13}{*}{ No } & \multirow[t]{13}{*}{75} \\
\hline & & & Cellulitis & State site & & \\
\hline & & & Current ulcer & Left or right foot & & \\
\hline & & & Previous ulcer & \multirow{10}{*}{$\begin{array}{l}\text { For Other state } \\
\text { condition }\end{array}$} & & \\
\hline & & & Normal & & & \\
\hline & & & Interdigital rash & & & \\
\hline & & & Hyperhydrotic & & & \\
\hline & & & Hypohydrotic & & & \\
\hline & & & Fissure & & & \\
\hline & & & Corns and Callus & & & \\
\hline & & & Extravasation tissue & & & \\
\hline & & & Blisters & & & \\
\hline & & & Other & & & \\
\hline \multirow[t]{5}{*}{ Nail conditions } & \multirow[t]{5}{*}{ Yes } & \multirow[t]{5}{*}{100} & Onychauxis & Tick box State site & \multirow[t]{5}{*}{ No } & \multirow[t]{5}{*}{100} \\
\hline & & & Onychomycosis & Left or right foot & & \\
\hline & & & Paronychia & \multirow{3}{*}{$\begin{array}{l}\text { For Other state } \\
\text { condition }\end{array}$} & & \\
\hline & & & Onychocryptosis & & & \\
\hline & & & Other & & & \\
\hline Smoking & Yes & 100 & & Yes/no & Unclear & 75 \\
\hline \multirow[t]{6}{*}{ Footwear } & \multirow[t]{6}{*}{ Yes } & \multirow[t]{6}{*}{100} & Type & Tick box & \multirow[t]{2}{*}{ Yes } & \multirow[t]{2}{*}{100} \\
\hline & & & & State Type & & \\
\hline & & & Habits & Worn always & Yes & 100 \\
\hline & & & & Outdoors only & & \\
\hline & & & & Indoors only & & \\
\hline & & & & Never & & \\
\hline $\begin{array}{l}\text { Significant Surgical } \\
\text { History }\end{array}$ & Yes & 100 & & Location, Details & Yes & 100 \\
\hline
\end{tabular}


Table 8 Delphi results: Round 4-Additional suggested items to be added to final tool

\begin{tabular}{|c|c|}
\hline Proposed additions to the assessment tool & Further details \\
\hline $\begin{array}{l}\text { Social to be added to the demographics } \\
\text { section }\end{array}$ & $\begin{array}{l}\text { This will include smoking and additionally alcohol due to the high reported incidence of alcoholism } \\
\text { by the panel members }\end{array}$ \\
\hline \multicolumn{2}{|l|}{ Filarial to the medical history section } \\
\hline $\begin{array}{l}\text { Patient complains of (in relation to the foot } \\
\text { condition) }\end{array}$ & To record patients chief complaint \\
\hline Classification and stage of diabetic foot & To aid putting patients onto the correct management plan \\
\hline \multirow[t]{6}{*}{ Management plan } & This would include \\
\hline & Initial Return period \\
\hline & Next screening \\
\hline & Treatment (interventions to circle) \\
\hline & Referral (departments to circle) \\
\hline & As a quick reference to past treatments \\
\hline Diagnosis/summary & A small section at the end of the tool to allow some notes to be written about the patients diagnosis \\
\hline
\end{tabular}

Table 9 Delphi results: Round 5-Alterations to methods of recording

\begin{tabular}{|c|c|c|c|c|c|c|}
\hline $\begin{array}{l}\text { Risk factors } \\
\text { confirmed for } \\
\text { inclusion in the } \\
\text { Pilot tool }\end{array}$ & $\begin{array}{l}\text { Tests and assessment } \\
\text { methods confirmed for } \\
\text { inclusion in the Pilot tool }\end{array}$ & $\begin{array}{l}\text { Method of } \\
\text { recording tests and } \\
\text { assessment } \\
\text { methods }\end{array}$ & $\begin{array}{l}\text { Practicality of proposed } \\
\text { test/assessment and } \\
\text { method of recording }\end{array}$ & $\begin{array}{l}\text { Suggested } \\
\text { alternative }\end{array}$ & $\begin{array}{l}\% \text { expert } \\
\text { consensus }\end{array}$ & $\begin{array}{l}\text { Comments or } \\
\text { amendments on } \\
\text { previous round }\end{array}$ \\
\hline & Amputation & $\begin{array}{l}\text { Site and Surgical/ } \\
\text { traumatic/auto }\end{array}$ & No & $\begin{array}{l}\text { Yes/no + recorded } \\
\text { on foot picture }\end{array}$ & 100 & $\begin{array}{l}\text { Not challenged } \\
\text { and therefore }\end{array}$ \\
\hline \multirow[t]{14}{*}{ Skin conditions } & \multirow[t]{2}{*}{ Fungal } & Tick box & \multirow[t]{14}{*}{ No } & \multirow{14}{*}{$\begin{array}{l}\text { Yes/no + recorded } \\
\text { on foot picture }\end{array}$} & \multirow[t]{14}{*}{100} & \\
\hline & & State site & & & & \\
\hline & Cellulitis & Left or right foot & & & & \\
\hline & Current ulcer & \multirow{11}{*}{$\begin{array}{l}\text { For Other state } \\
\text { condition }\end{array}$} & & & & \\
\hline & Previous ulcer & & & & & \\
\hline & Normal & & & & & \\
\hline & Interdigital rash & & & & & \\
\hline & Hyperhydrotic & & & & & \\
\hline & Hypohydrotic & & & & & \\
\hline & Fissure & & & & & \\
\hline & Corns and Callus & & & & & \\
\hline & Extravasation tissue & & & & & \\
\hline & Blisters & & & & & \\
\hline & Other & & & & & \\
\hline \multirow[t]{5}{*}{ Nail conditions } & Onychauxis & Tick box & \multirow[t]{5}{*}{ No } & \multirow{5}{*}{$\begin{array}{l}\text { Yes/no + recorded } \\
\text { on foot picture }\end{array}$} & \multirow[t]{5}{*}{100} & \\
\hline & Onychomycosis & State site & & & & \\
\hline & Paronychia & Left or right foot & & & & \\
\hline & Onychocryptosis & \multirow{2}{*}{$\begin{array}{l}\text { For Other state } \\
\text { condition }\end{array}$} & & & & \\
\hline & Other & & & & & \\
\hline Smoking & & Yes/no & Unclear & $\begin{array}{l}\text { Include smoking, } \\
\text { snuff, Chewing }\end{array}$ & 100 & \\
\hline
\end{tabular}


Table 10 Delphi results: Round 5-Additional items to be added to final tool

\begin{tabular}{|c|c|c|c|c|}
\hline $\begin{array}{l}\text { Proposed additions to the } \\
\text { assessment tool }\end{array}$ & Further details & $\begin{array}{l}\text { Acceptance of } \\
\text { additional item }\end{array}$ & $\begin{array}{l}\% \text { expert } \\
\text { consensus }\end{array}$ & $\begin{array}{l}\text { Comments or } \\
\text { amendments } \\
\text { on previous round }\end{array}$ \\
\hline $\begin{array}{l}\text { Social to be added to the } \\
\text { demographics section }\end{array}$ & $\begin{array}{l}\text { This will include smoking and additionally alcohol due to the } \\
\text { high reported incidence of alcoholism by the panel members }\end{array}$ & Yes & 100 & $\begin{array}{l}\text { Not challenged and } \\
\text { therefore included }\end{array}$ \\
\hline $\begin{array}{l}\text { Filarial to the medical history } \\
\text { section }\end{array}$ & & Yes & 100 & \\
\hline $\begin{array}{l}\text { Patient complains of } \\
\text { (in relation to the foot condition) }\end{array}$ & To record patients chief complaint & Yes & 100 & \\
\hline $\begin{array}{l}\text { Classification and stage of } \\
\text { diabetic foot }\end{array}$ & $\begin{array}{l}\text { To aid putting patients onto the correct } \\
\text { management plan }\end{array}$ & Yes & 100 & \\
\hline \multirow[t]{6}{*}{ Management plan } & This would include & Yes & 88 & \\
\hline & Initial Return period & & & \\
\hline & Next screening & & & \\
\hline & Treatment (interventions to circle) & & & \\
\hline & Referral (departments to circle) & & & \\
\hline & As a quick reference to past treatments & & & \\
\hline Diagnosis/summary & $\begin{array}{l}\text { A small section at the end of the tool to allow some notes to } \\
\text { be written about the patients diagnosis }\end{array}$ & No & 88 & $\begin{array}{l}\text { Not challenged and } \\
\text { therefore excluded }\end{array}$ \\
\hline
\end{tabular}

health problems present in their clinics and in India on a daily basis. Critically, it was this expertise, not expertise in best practice of foot health, that was needed to drive creation of shared solutions for the foot assessment tool [22-25].

The Delphi has the further advantage of offering anonymity [26]. This helped prevent domination of some over others due to caste, gender, authority or personality. It is recognized that this culture and

Table 11 Items to be highlighted as red flags in final tool

\begin{tabular}{ll}
\hline Medical conditions & Diabetes \\
\hline & Leprosy \\
& Buergers disease \\
& PVD \\
& Venous insufficiency \\
& Rheumatoid arthritis/SLE \\
& Filarial \\
& Current Ulcer \\
Skin conditions & Previous Ulcer \\
& Cellulitis \\
& Charcot \\
Deformity & Previous amputation \\
PVD & IC \\
& Rest pain \\
Neurological system & Less than 8 sites \\
& Hypo pigmented lesions \\
\hline
\end{tabular}

environment may influence the success of a change management process [27].

According to the institutional theory [27], the institutional environment can be defined by its structure and culture. Hofstede [28] identifies 'power distance' (PDI) as the extent to which the less powerful members of institutions accept and expect that power be distributed unequally, in this context it is the caste system [29]. Hofstede [28] also identified that gender inequality influences the culture of an institution and in India the male gender is viewed as superior with the role of decision makers [30, 31, 32]. Hence, we considered the anonymity of the Delphi method would overcome some of these influences in order to achieve completion of the action research cycle.

There are limitations to the use of the Delphi method [33]. There is no reported standard for the size and selection of panel members, with studies using a range of 4-171 experts, [34-36]. Further, there is no "typical" Delphi method, rather that the method is modified to suit the context and the research question. Additionally, there is no evidence of reliability of the method and as a result it cannot be certain that if the same task were given to two or more different panels, would the same results be obtained. Furthermore the lack of opportunity to clarify responses can create interpretation difficulties for both the researchers and participants [37], especially when working with participants whose first language is not English. The Delphi method has been used successfully to develop data collection tools previously [38-43] but to date, this is the first time 
that a delphi has been used within an action research approach to bring about local ownership of a clinical problem and produce a solution which was the development of the Salford Indian Foot health assessment.

However, the SIFT is not without its limitations and clearly focuses on the medical and podiatric presentations of patients following a biomedical model of health care. Although it collects some data in relation to alcohol, tobacco use and footwear practices, the wider bio psychosocial aspects $[44,45]$ are absent. It is important to handle the three together, as literature suggests that patient perceptions of health, threat of disease and barriers to good health in a patient's social or cultural environment influences the likelihood that they will engage in good health behaviors [46]. The dominance of the biomedical model may reflect wider cultural approaches to health care.

Use of the tool in clinical practice to assess consistency and construct validity are ongoing, as at this stage we have not undertaken any formal quantitative analysis of the SIFT. However, the first stages of the validation process have included a pilot of the tool in clinical practice. This has shown variation among some clinicians where there is subjectivity in the assessment decision which is similar to what Thompson et al. 2004 found. [47]. The pilot also identified that there was a training need for objective clinical testing. The use of 'objective' diagnostic equipment has been shown to reduce variability in the conduct of clinical tests [48-50]. It has also been reported that the opportunity to make modifications based upon reflections in practice can be useful in improving validity and reliability when generalists use structured screening tools [51]. Further testing is required to measure the reliability of the instrument and thereby determine the degree of consistency between the scores obtained at two or more independent times of testing by measuring inter rater reliability [52].

The participants reflected on the final tool and it components and this highlighted the need for training to support its use [53, 54]. Hence, as well as the tool being the vehicle for assessing foot health, it aided identification of training needs in foot health assessment and management including an increased awareness of the importance of simple lesions, the importance of regular screening including vascular, neurological, wound and offloading principles in the high risk foot. Further, the participants identified a need for sustainable training [55] and to meet this requirement a 'train the trainer' programme was delivered. The combination of the action research approach to develop the SIFT and the training programme aligned with the recommendation for multiple strategies to achieve improved knowledge and change in behavior made by Halfens and van Linge (2003) [6] and when combined with the education of the local 'opinion leader', both the need and the process of change was optimized $[56,57]$.
This research has facilitated the action research cycle that initially identified the need for change [5]. Through the phases of action and implementation the authors have facilitated the development of a locally defined, context specific assessment tool to aid identification of foot problems and hence the implementation of appropriate and timely management for individual patients. Further, the information gathered from this tool can be used to identify areas for service improvement.

\section{Conclusion}

The action research process has given local ownership of the solution to practitioners and produced the first systematically developed evidence based foot health assessment tool to be used in India. The first step identified by the participating practitioners [5], as being pivotal to achieving better outcomes for patients. Engagement in the action research process has given practitioners the opportunity to reflect on current practice and bring about change within their service and individual clinical practice.

\section{Additional files}

Additional file 1: Copy of Salford Indian Foot Health Assessment

Tool (SIFT). (DOC $170 \mathrm{~kb}$ )

Additional file 2: Learning points for foot health assessment and management training. (DOC $33 \mathrm{~kb}$ )

\section{Competing interests}

The author(s) declared no potential conflicts of interest with respect to the research, authorship, and/or publication of this article.

\section{Authors' contribution}

MHB was responsible for the study design, collection and analysis of the data and preparing the manuscript. MC participated in the delivery of the training programme identified by the study. CN and AW contributed to study design and preparing the manuscript. All authors read and approved the final manuscript.

\section{Funding}

The author received no financial support for the research, authorship, and/or publication of this article.

Received: 17 April 2015 Accepted: 3 September 2015

Published online: 16 September 2015

\section{References}

1. International Diabetes Federation, IDF Diabetes Atlas 6th ed. 2013, Retrieved from http://www.idf.org/diabetesatlas.

2. 5th International Symposium on The Diabetic Foot, The Diabetic Foot Journal. 2007; 10(2): 108-110.

3. Bakker K, Abbas ZG, Pendsey S. Step by Step, improving diabetic foot care in the developing world. A pilot study for India, Bangladesh, Sri Lanka and Tanzania. Practical Diabetes Int. 2006;23:365-9.

4. Apelqvist J. Diabetic foot ulcers: evidence, cost and management. The diabetic Foot J. 2007;10:6-8.

5. Harrison-Blount M, Cullen M, Nester CJ, Williams AE. The assessment and management of diabetes related lower limb problems in India-an action research approach to integrating best practice. Journal of foot and ankle research., 2014. doi:10.1186/1757-1146-7-30.

6. Halfens R, Van Linghe R. Dissemination and implementation of knowledge. State of the art studies. The Netherlands: LEW; 2003. 
7. Funk G, Champagne MT, Wiese RA, Tornquist EM. Barriers to using research findings in practice. The clinician's perspective. Applied Nursing Res. 1991;4(2):90-5.

8. Kitson A, Harvey G, McCormack B. Enabling the implementation of evidence based practice: a conceptual framework. Quality in Health Care. 1998;7:149-58.

9. Denis JL, Hebert Y, Langley A, Lozeau D, Trottier LH. Explaining diffusion patterns for complex health care innovations. Health Care Management Re- view. 2002;27(3):60-73.

10. Dopson S, FitzGerald L, Ferlie E, Gabbay J, Locock L. No magic targets! Changing clinical practice to become more evidence based. Health Care Management Rev. 2002;27(3):35-47.

11. National Institute for Clinical Excellence. Clinical Guidelines and Evidence Review for Type 2 Diabetes: Prevention and Management of Foot Problems. Clinical guideline 10. 2004. Retrieved from http//www.nice.org.uk/CG10

12. Streiner DL, Norman GR. Health measurement scales: a practical guide to their development and use. 4th ed. Oxford: Oxford University Press; 2008.

13. Cook C, Brismée J, Pietrobon R. Development of a quality checklist using Delphi methods for prescriptive clinical prediction rules: the QUADCPR. J Manipulative Physiol Ther. 2010;33:29-41.

14. Streiner DL, Norman GR. Health measurement scales: a practical guide to their development and use. Oxford: Oxford University Press; 1995.

15. Diamonds IR, Grant RC, Feldman BM, Pencharz PB, Ling SC, Moore AM, et al. Defining consensus: A systematic review recommends methodologic criteria for reporting of Delphi studies 2013. Retrieved from.

16. Haines $S$, Baker $T$, Donaldson M. Development of a physical performance assessment checklist for athletes who sustained a lower extremity injury in preparation for return to sport: A Delphi study. Int J Sports Phys Ther. 2013;8(1):44-53.

17. Deming Hedman L, Morris DM, Graham CL, Brown CJ, Ford MP, Ingram DA, et al. Locomotor requirements for bipedal locomotion: A Delphi survey. Physical Therapy. 2014;94(1):52-67. doi:10.2522/ptj.20120514.

18. Noffke S, Somekh B. Action research. In: Lewin BSC, editor. Research methods in the social sciences. London: Sage; 2005. p. 89-96.

19. Pill J. The Delphi Method: substance, context, a critique and annotated bibliography. Socio Economic Planning Sci. 1971:5:57-71.

20. SNCPR. The Delphi Technique in Pain Research. The Delphi Technique in Pain Research. Scottish Network for Chronic Pain Research: SNCPR; 2001. Retrieved from http://www.sncpr.org.uk/delphi.htm.

21. Kerr M. The Delphi Process. The Delphi Process 2002 City: Remote and Rural Areas Research Initiative, NHS in Scotland., 2001; Retrieved from http://www.rararibids.org.uk/documents/bid79-delphi.htm.

22. Tripp-Reimer T, Choi E, Skemp Kelley L, Enslein JC. Cultural barriers to care: inverting the problem. Diabetes Spectrum. 2001;14(1):13-22. doi:10.2337/diaspect.14.1.13.

23. Goodman CM. The Delphi technique: a critique. J Advanced Nursing. 2006;12(6):729-34. doi:10.1111/j.1365-2648.1987.tb01376.x.

24. Pendsey S, Abbas ZG. World Diabetes Federation report. 2008;03-056. http://www.worlddiabetesfoundation.org/sites/default/files/ AR2007_reduced.pdf

25. Baker J, Lovell K, Harris N. How expert are the experts? An exploration of the concept of 'expert' within Delphi panel techniques. Nurse Researcher. 2006;14:59-69

26. Strauss HJ, Ziegler HL. The Delphi and its use in social science research. J Creative Behav. 1975;9:253259.

27. Meyer JW, Boli J, Thomas GM. Ontology and rationalization in the Western Cultural Account'. In: Scott WR, Meyer JW, editors. Institutional Environments and Organizations: Structural Complexity and Individualism. Thousand Oaks: Sage Publications; 1994. p. 9-27.

28. Hofstede G. Culture's Consequences: Comparing Values, Behaviors, Institutions, and Organizations Across Nations. Thousand Oaks, CA: Sage Publications; 2001.

29. Chhokar JS, Brodbeck FC, House RJ. India. Diversity and Complexity in Action. In: House RJ, editor. Culture and leadership across the world: The GLOBE Book of In-Depth Studies of 25 Societies. New York: Lawrence Erlbaum Associates; 2008. p. 971-1020.

30. Sinha JBP, Kanungo RN. Context Sensitivity and Balancing in Indian Organization behaviour. Int J Psychol. 1997;32(2):93-105.

31. Cappelli P, Singh H, Singh J, Useem M. The India Way: How India's Top Leaders are Revolutionizing Management. Boston: Harvard Business Press; 2010.

32. Garg RK, Singh TP. Management of Change - A Comprehensive Review. Global J Flexible Systems Management. 2006;7(1/2):45-60.
33. Williams PL, Webb C. The Delphi technique: a methodological discussion. J Advanced Nursing. 1994;19:180-6.

34. Adler M, Ziglio E. Gazing into the oracle: The Delphi Method and its application to social policy and public health. London: Jessica Kingsley Publishers; 1996.

35. Linstone $\mathrm{H}$, Turloff $\mathrm{M}$. The Delphi method: Techniques and applications. London, UK: Addison-Wesley; 1975.

36. Rowe G, Wright G. The Delphi technique as a forecasting tool: Issues and analysis. Int J Forecasting. 1999;15(4):353-75.

37. Delbeq A, Van de Ven A, Gustafson DH. Group techniques for program planning: A guide to nominal group and Delphi processes. Glenview, USA: Scott, Foresman and Company; 1975.

38. Whiting P, Rutjes AWS, Reitsma JB, Bossuyt PMM, Kleijnen J. The development of QUADAS: a tool for the quality assessment of studies of diagnostic accuracy included in systematic reviews. BMC Medical Res Methodol. 2003;3:1-25.

39. Fahera $S$, Carpenter $L$, Seers K. Development of a tool to rate the quality assessment of randomized controlled trials using a Delphi technique. J Advanced Nursing. 1997;25(6):1262-8.

40. Nekolaichuk CL, Fainsinger RL, Lawlor PG. The Edmonton Classification System for Cancer Pain: Comparison of pain classification features and pain intensity across diverse palliative care settings in eight countries. J Palliative Medicine. 2013;16(5):516-23.

41. Hagen NA, Stiles C, Nekolaichuk C, Biondo P, Carlson LE, Fisher K, et al. The Alberta Breakthrough Pain Assessment Tool for cancer patients: a validation study using a Delphi process and patient think-aloud interviews. J Pain Symptom Management. 2008;35(2):136-52.

42. Palter VN, MacRae HM, Grantcharov TP. Development of an objective evaluation tool to assess technical skill in laparoscopic colorectal surgery: a Delphi methodology. Am J Surg. 2011;201(2):251-9.

43. Ramanan AV. Developing a disease activity tool for systemic-onset juvenile idiopathic arthritis by international consensus using the Delphi approach. Rheumatology. 2005;44(12):1574-8.

44. Santrock JW. A Topical Approach to Human Life-span Development. 3rd ed. St. Louis, MO: McGraw-Hill; 2007.

45. Halligan PW, Aylward M, editors. The Power of Belief: Psychosocial influence on illness, disability and medicine. UK: Oxford University Press; 2006.

46. DiMatteo MR, Haskard KB, Williams SL. Health beliefs, disease severity, and patient adherence: A meta-analysis. Medical Care. 2007:45:521-8. doi:10.1097/mlr.0b013e318032937e.

47. Thompson L, Nester C, Stuart L, Wiles P. Interclinician variation in diabetes foot assessment-a national lottery? Diabetes UK. Diabetic Medicine 2004; 196-199 doi:10.1111/j.1464-5491.2004.01397.x.

48. Apelvist J, Bakker K, Van Houtum W, Nabuurs-Fransen M, Schaper N International Consensus on the Diabetic Foot. Amsterdam: International Working Group on the Diabetic Foot; 1996.

49. Peters JG, Lavery LA. Effectiveness of the Diabetic Foot Risk Classification System of the International Working Group on the Diabetic Foot. Diabetes Care. 2001;24:1442-7.

50. Redelmeier D, Tu J, Schull M, Ferris L, Hux JE. Problems for clinical judgement: Obtaining a reliable past medical history. Can Med Assoc J. 2001;164:809-13.

51. Bower VM, Hobbs M. Validation of the Basic Foot Screening Checklist. A Population Screening Tool for Identifying Foot Ulcer Risk in People with Diabetes Mellitus. Journal of the American Podiatric Medical Association., 2009;99(4).

52. Toro B, Nester CJ, Farren PC. The Development and Validity of the Salford Gait Tool: An Observation-Based Clinical Gait Assessment Tool. Arch Phys Med Rehabil. 2007;88(3):321-7.

53. Mclnnes A, Baird S. Diabetic foot care training in the absence of podiatrists Diabetic Foot J. 2009;12(3):104-10.

54. Murugesan N, Shobana R, Snehalatha C, Kapur A, Ramachandra A. Immediate impact of a diabetes training programme for primary care physicians- An endeavour for national capacity building for diabetes management in India. Diabetes Research and Clinical Practice. 2009;83:140-4.

55. Bakker K, Abbas ZG, Pendsey S. Step by step, improving diabetic foot care in the developing world. Practical Diabetes Int. 2006;23(8):365-9.

56. Thompson D, Estabrooks C, Scott-Findlay S, Moore K, Wallin L. Interventions aimed at increasing research use in nursing: A systematic review. Implementation Science. 2007;2(1):1-16.

57. Dufault MA, Bielecki C, Collins E, Willey C. Changing nurses' pain assessment practice: A collabo- rative research utilization approach. J Advanced Nursing. 1995;21(4):634-45. 